\title{
Yörük Kışlağından Kırsala, Kırsaldan Kentsele: Döşemealtı'nda Sosyal Değişme ve Kırsal Soylulaştırma
}

\section{From Nomad Winter Quarters to Rural, From Rural to Urban: Social Change and Rural Gentrification in Dössemealtı}

\author{
Sevinç GÜÇLÜ*
}

0000-0002-3814-3918

\section{MAKALE BİLGISII}

Başvuru: 23. 03. 2021

Düzeltme Talebi: 17. 05. 2021

Son Düzeltme: 26. 07. 2021

Kabul: 29. 07. 2021

Online Yayım: 15. 08. 2021

\section{Anahtar Kelimeler:}

Kent Sosyolojisi

Kirsal Alanlar Sosyolojisi

Soylulaștırma

Sosyal Değişme

Döșemealtı

\section{ARTICLE INFO}

Submitted: 23. 03. 2021

Revision Requested: 17. 05. 2021

Final Revision Received: 26. 07. 2021

Accepted: 29. 07. 2021

Published Online: 15. 08. 2021

\section{Keywords:}

Urban Sociology

Rural Sociology

Gentrification

Social Change

Döşemealtı öz

Bu çalışmada 2000'lere kadar kırsal karaktere sahip olan Antalya Döşemealtı ilçesinin nüfus verileri ve gözlemler ışığında sosyal değişme ve kırsal soylulaştırma incelenmiştir. Günümüzde kentsel kesimde karşılaşılan kentsel değișim ve soylulaştırma pratikleri kırsal kesimde de deneyimlenmektedir. Küreselleşme süreci ile bazı kırsal alanlar (doğal, tarihi ve turistik özellikleri nedeniyle) birer meta haline dönüşmeye başlamıştır. Kırsal alanlar, kente göre daha doğal, sağlıklı ve kentin karmaşasından uzaktır. Ulaşım ve iletişim teknolojilerinin de gelişmesi ile bu durum kentten kıra göçlere neden olmakta, kırsal alanda hem ekonomik hem de sosyo-kültürel değişimlere yol açmaktadır. Literatürde kırsal soylulaștırma çalıșmaları artmaya başlamıştır. Kırsal alana yerleșen kentliler, sahip oldukları ekonomik güç ve sınıfsal farklılıkları nedeni ile kırsal alanda baskın hale gelmekte, kente özgü alışkanlıkları ve beğenileri kırsal alana taşımaktadırlar. Ancak bu durum kırsal alanda da kentsel alanda yaşanan sosyal ve ekolojik problemlerin ortaya çıkmasına neden olmaktadır. Ayrıca kentsel kesimden göç edenler ile kırsal alanın sakinleri arasında da etkileşim sorunları ortaya çıkabilmektedir. Bu anlamda çalışmanın kırsal alanlar sosyolojisi açısından literatüre katkıda bulunması beklenmektedir.

\section{A B S T RACT}

In this study, social change and rural gentrification were examined in the light of population data and observations in Antalya Döșemealt district, which had a rural character until the 2000s. Today, urban change and gentrification practices encountered in urban areas are also experienced in rural areas. Some rural areas (due to their natural, historical, and touristic features) have started to turn into commodities with the globalization process. Rural areas are more natural, healthy, and far from the chaos of the city compared to the city. With the development of transportation and communication technologies, this situation causes migration from the city to the countryside and causes economic and socio-cultural changes. Rural gentrification studies have started to increase in the literature. Urban dwellers who settle in rural areas become dominant in rural areas due to their economic power and class differences. They carry their city-specific habits and tastes to rural areas. However, this situation causes the emergence of social and ecological problems in rural areas and urban areas. In addition, interaction problems may arise between migrants from urban areas and residents of rural areas. In this sense, the study is expected to contribute to the literature regarding the sociology of rural regions.

"Yazar İletişim/ Corresponding Author: Sevinç Güçlü (Prof. Dr.), Akdeniz Üniversitesi, Edebiyat Fakültesi, Sosyoloji Bölümü, Antalya, Türkiye 


\section{Giriş}

$\mathrm{Bu}$ çalışmada metropol kentlerin nüfus ve yapılaşma açısından giderek yoğunlaşması sonucunda yakın çevrelerinde yer alan kırsal alanlardaki yerleşimlerin nüfus artışı ile karşılaşması ve sosyal yapılarının değişiminin, kentsel saçaklanma ve kırsal soylulaştırma kavramları açısından değerlendirilmesi ele alınmaktadır. Yeni mekân tartışmalarında kent-kır ölçeklerinin geçişkenliği ve belirsizliği, kırın nerede bittiği, kentin nerede başladığı sıklıkla vurgulanmaktadır. Toplumda yaşanan sosyo-ekonomik değişimler kent nüfusunun tercihlerini etkileyerek, kentin farklı bölgelerine, özellikle de yakın kırsal bölgelere taşınmaları sonucunu doğurmuştur Soylulaştırma, genellikle kent ölçeğinde teorize edilmekte, bu çalışmada ise kırsal ölçekteki yansımaları ele alınmaktadır. Kentte sıklıkla karşılaşılan soylulaştırma pratiklerinin kırsal kesimde nasıl deneyimlendiği ele alınacaktır. Antalya kenti de 2000 'den sonra yoğun nüfus baskısı ile karşılașmış ve Döşemealtı, Kepez, Varsak, Lara, Kundu bölgelerinde yeni yaşam alanları ortaya çıkmıștır. Bu bölgelere hem yeni kırsal göçler hem de kent merkezinden göçler söz konusu olmuştur. Bu durum yerleşilen kırsal alanların sosyal ve ekonomik yapılarını etkilemiştir. Makalemizde 2000'lere kadar kırsal karaktere sahip olan Döşemealtı ilçesi bağlamında nüfus verileri ve gözlemler sosyolojik olarak değerlendirilecektir.

\section{Soylulaştırma Sürecini Kavramsallaştırmak}

Soylulaştırma süreci sosyal ilişkilerin mekânda vuku bulmasının, toplumsal ve iktisadi değişimin yapılı çevreyi etkilemesinin bir örneği olarak anlaşılmalıdır. Castells'in de belirttiği gibi,

"Kentler tüm sosyal gerçeklik gibi fiziksel varlıklarının yanı sıra kültürel anlamları, sosyal örgütlenmedeki ve insanların yaşamlarındaki rolleri açısından tarihsel ürünlerdir. Kentsel değişimin temel boyutu kentsel anlam üzerine toplumsal sinıflar ile tarihsel aktörler arasındaki tartışma, sosyal yapıda mekânsal biçimlerin önemi ve tüm sosyal yapı ile ilișkili olarak kentlerin bağlamı, hiyerarşisi ve kaderidir."

Soylulaştırma değişen sosyal ilișkilerin ve toplumsal sınıfların mekandaki entegrasyonunun görünür bir ifadesi olmaktadır (Williams, 2015: 83-111).

Literatürde soylulaştırma geleneksel olarak kentsel araştırma gündemleri ile ilişkilendirilmiş olsa da kırsal alan araştırmacıları bu geleneksel kentsel temaları kırsal alanlara uyarlamışlardır. Birçok yönden kırsal soylulaştırma kentsel soylulaştırma ile çok benzerdir, her iki olgu da uzun zamandır orada yaşayanları yerinden etme, mekânı metalaştırma ve üretim alanlarından tüketim alanlarına geçişi içerir. Kırsal soylulaştırmada anahtar öge, "doğanın" göreceli önemidir. Sermaye ve doğa arasındaki ilișki, incelenen önemli bir konudur. Soylulaştırma kavramı kent sosyolojisinde eleştirel bağlamda kullanılmaktadır. Mekânın metalaşması ve mekânda sınıfsal yapının değişimi olarak ele alınmaktadır. Bu çalışmada da incelenen alanın kırsal niteliklerinin dönüşümü ve mekânın metalaşması, toprakların el değiştirmesi anlamında düşünülmelidir.

Kırsal alanlarda yürütülen ekonomik faaliyetler toprağa ve hayvancllığa dayanmaktadır. Dolayısıyla tarım ve hayvancılık en önemli geçim kaynakları arasındadır. Kapitalizm ile birlikte gelişen karlılık ve pazar için üretim düşüncesi tarım alanlarında büyük aile tarımcllı̆̆ ve küreselleşen tarım şirketleri aracılığıyla küçük tarım işletmelerini özellikle gelişmekte olan ülkelerde yok olma durumuna getirmiștir. Özellikle makineleşmenin gelişmesi ile birlikte tarımsal iş gücüne duyulan ihtiyaç da azalmıştır. Bu bağlamda da kırsal alanlarda yaşayan nüfus kentlere doğru akın etmiş kalabalıklaşan kentler genişlerken tarım alanları giderek daralmıştır. Dolayısıyla sadece yaşam biçimini devam ettirmek için tarımsal faaliyetler ile uğraşan kırsal nüfus hem azalmış hem de yoksullaşmıştır. Bunun sonucunda kırsal alanlar kapitalizmin gelişmesi ile birer artı-değer formuna dönüștürmekte ve kırsal soylulaştırma süreci söz konusu olmaktadır. Egemen eğilim başlangıçta daha ucuz evlerle, yakın dönemde ise sağlıklı huzurlu doğal bir yaşam biçiminin pastoral bir vizyonu ile cezbedilen orta sınıf göçmenlerin köylere göçmesi şeklindedir. (Özgen, 2018: 30) 


\begin{abstract}
"Küreselleșme süreci ile bazı kırsal alanlar birer meta haline dönüşmeye başlamıştır. Bu metalaşma sürecinde kullanılan temel argümanlar ise; kentteki yașam kalitesinden farklı bir yaşam kalitesi ve kente göre daha sağlıklı ve huzurlu bir yaşamdır. Bu bağlamda kırsal alanlar, kentteki bireyler için; kentin karmașıllı̆ğndan, yoğunluğundan kısa bir süre de olsa kurtulup kendini doğal yaşama bıraktığı alternatif bir yaşam biçimini oluşturmaktadır. Yani kırsal alanlar kentli bireyler için alternatif bir yaşam biçimi olarak sunulmakta, metalaştırılmaktadır. Ancak gelişen süreç içerisinde bu romantik söylemler yerini ekonomik metalaşmaya, tüketim üzerinden kırsal alanların dönüşümüne, yapay doğallıkların oluşmasına neden olmaktadır. Tarımsal arazi ve konutlarda meydana gelen bu temel değișim kırsal alana özgü geleneklerinde değişmesine neden olmaktadır. Bu açıdan kırsal soylulaştırma süreci hem ekonomik hem de sosyo kültürel açıdan kırsal yaşamı derinden etkilemektedir." (Özen, 2019: 45-48)
\end{abstract}

Kırsalda yaşanan dönüşümlerin görünür olduğu bir diğer alan ise kırsalın giderek kentleşmesi ve kentlerden kırsal alanlara göç olarak ortaya çıkmasıdır. Özellikle ulaşım ve iletişim teknolojilerinin gelişmesi, bazı mesleklerin evlerden icra edilebilir hale gelmesi ile köylerde ikamet etmek isteyen insanların sayısında artışa neden olmaktadır. Literatürde counter-urbanization olarak kavramsallaştırılan bu süreçler esasında kentlerden köylere doğru bir karşı göç hareketine gönderme yapmaktadır. Kavram, basitçe köylerde yaşamaya başlayan kentli çalışanlara gönderme yapmaktadır. Kentlerdeki geniș iș imkanlarından vazgeçmeden kırsal alanlarda ikamet amacıyla kırsala doğru bir göç anlamına gelmektedir. (Perkins, 2006: 243-258)

Kırsalın yeni sakinleri, köylerde yeni ilişki biçimlerinin doğmasına neden olmaktadır: Yabancı kavramı. Kırsal alandaki güvene dayalı ilişkiler yok olmaktadır. Köyde yaşayan ama toprakla ilgisi olmayan birey tipi yaygınlaşabilmektedir. Bu süreçte köy tanımı da değişmektedir. Kırsal alanda bir yandan kentten uzak, konforlu bir yaşam tarzı, öte yandan bir yatırım ortaya çıkmaktadır.

Kıra göç eden kentlilerin, geldikleri mekânı olumlu yönde dönüștürdüğüne dair hatırı sayılı bir literatür olduğunu belirten Orhan ve Güneş, yaptıkları literatür taraması ışığında, orta sınıf soylulaştırıcıların yerleştikleri yeni mekânda konfor ve estetik ölçütlerini önemsedikleri için çevre örgütleri ve siyasi kurumlar aracıllğıyla gittikçe artan yerel güçlerini mobilize ettiklerini ve böylelikle yereldeki aktivizmi olumlu yönde etkilediklerini bulguladığını belirtmektedir. Yine toprağa dönüş hareketinin ve kıra göç edenlerin kırsal toplumu dönüștürme potansiyeli olduğunu belirtmektedir. Bu kişilerin çevre örgütlerine üyeliğinin yüksek olduğunu ve sosyal adalet prensibine göre hareket etme eğiliminde olduklarını vurgulamaktadır. Kıra yeni gelenler daha eğitimlidir ve bu farklılıkları bölgenin karşılaştığı çevre sorunlarının çözümünde önemli etkiye sahip olabilir (Orhan ve Yücel, 2019: 8- 38)

Kentlerin kalabalığından, yoğun temposundan uzaklaşmak, doğa ile baş başa kalmak için kırsal alanlara gelen kentliler bir süre sonra yerleștikleri köylerin sosyoekonomik, sosyokültürel ve mekânsal yapısını etkilemektedirler. Kırsal soylulaştırma olarak tanımlanan bu süreç artan gayrimenkul değerleri nedeniyle yerel halkın mülksüzleşmesine ve kıra özgü yaşamının yok olmasına yol açmaktadır.

"Türkiye kırsalında bölgesel farklıklar göstermekle birlikte yoksulluk, isssizlik, temel hizmetlere erişememe gibi sorunlar hala çözülebilmiş değildir. Bu nedenle ülkemizde kırsal alanlara yönelik stratejiler çoğunlukla kalkınma odaklıdır ve özellikle tarım dışı istihdamı artıran "kırsal turizm" modelleri önerilmektedir. Diğer yandan kırsal kültürel mirasın korunması, kırsal alanların planlanması ve yönetimi konularında yaşanan yetersizlikler, turizm ve soylulaștırma sürecine karșı kırsal alanları ve kırsal toplulukları savunmasız bırakmaktadır." (Uysal-Başaran ve Sakarya, 2012:2)

Kırsal soylulaştırma ile ilgili daha önce yapılan çalışmalar, yeni gelenlerin sosyoekonomik profilinin, tercihlerinin, yaşam biçimlerinin, konutların yıl içerisinde kullanım sürelerinin kırsal yaşamı etkilediğini göstermektedir. Kırsal alana yerleșen kentliler sahip oldukları ekonomik güç ve sınıfsal farklılıkları nedeniyle kırsal alanda baskın hale gelmekte, bir süre sonra kente özgü alışkanlıkları ve beğenileri kırsala taşımaktadırlar. Mevcut geleneksel yapı stoğunun restorasyonu, 
yenilenmesi, artan yeni yapıların yanı sıra kırsal alanın dokusuyla uyuşmayan (golf için ağaç keserek geniş yeşil alanlar açmak, avlanmayla beraber doğal hayata zarar vermek gibi) kullanımlara yer verilerek kırsal peyzaj değişime uğramaktadır. Değişen sınıfsal yapıya bağlı olarak, yeni gelenler ile yerel halk arasında kültürel çatışmalar ortaya çıkabilmektedir. Yükselen gayrimenkul değerleri uzun vadede yerel halkın, doğduğu köyden ayrılmasına neden olabilmekte, kırsal yerleşim tümüyle el değiştirebilmektedir. Tüm bu süreç kırsal ve kültürel peyzajın değişimine neden olmaktadır. Bu süreç sonunda ortaya köy görünümlü, kente özgü yaşam alışkanlıklarının hâkim olduğu yerleşimler çıkmaktadır. Kırsal peyzaj bir dekor haline gelmektedir. (Başaran-Uysal ve 2012:2)
"Soylulaştırma konusunda sinıfsal tartışmalar yapılmakta soylulaștırmada yeni orta sinıfların etkili olduğunu göstermektedir. Bourdieu (1986), sınıf ayrımları için ekonomik kültürel ve sosyal sermaye kavramlarını geliştirir. Ekonomik sermaye kavramı kişinin malvarlı̆̆, bireyin mesleği ve boş zaman aktiviteleri gösterirken kültürel sermayesi, kişinin eğitim seviyesi, baba mesleği ve benzeri bireyin entelektüel birikimini etkileyen göstergeleri ifade eder. Sosyal sermaye de bireyin toplum içerisindeki itibarı, saygınlı̆ı ve sosyal bağlarını kuracak birikimidir. Buna göre soylulaştirllan alanlar belli sinıfların kültürel tercihlerine yanıt verecek şekilde dönüsserek kültürel üretimin arttı̆ı çevreler haline gelmektedir." (Șen, 2005: 127-161)

20. yüzyılın ortalarından bu yana, nüfus hareketi eğilimleri yalnızca kırsal bölgelerden kentteki yeni kalıcı ikamet yerlerine göç değil, aynı zamanda nüfusun şehirden kent dışı ortamlara doğru ters hareketliliği biçimini de alıyor. Yeni biçimler alan ve farklı sosyal aşamaları içeren akışkan göç, (Bauman) tarafından sunulan akıcı modernite kavramı ile de uyumludur. Bu durum göç edilen yerdeki sosyal sınıf yapısının yeniden düşünülmesini de zorunlu kılar. Kırdan kente, kentten kıra göç dinamikleri, sosyoloji ile sosyal coğrafyayı yakınlaştırmakta sosyal alan, coğrafi alanı içine almakta ve dönüştürmektedir.

Bundan yüz yıl önce, kentleşme patlaması ve nüfusun kalabalık megapoller alanında yoğunlaşması birçok sorunu tetikledi. Sosyolojinin kurumsallaşması büyük ölçüde Chicago Okulu üyelerinin (Robert Park, Ernest Burgess, Louis Wirth, Thomas ve Florian Znaniecki vd) şehir ve kentsel yaşam üzerine çalışmalarının bir sonucu olarak ortaya çıtı. 20. Yüzyıl sosyolojisi kentsel sosyoloji haline geldi.

$\mathrm{Bu}$ alandaki klasikler kentsel ve kırsal toplulukların nasıl organize edildiğini karşılaştırdı. George Simmel, yaşam tarzı kavramını kullanarak şehri kırdan ayırmıştır. (Simmel, 2002) Ferdinand Tönnies, köyü kişisel ilişkilerin baskın olduğu bir "gemeinschaft" olarak görürken şehir, kararların "ortak iyiye" dayalı olarak alındığı ve resmi ilişkilerin hâkim olduğu bir "gesselschaft" idi. Max Weber, şehri endüstriyel yaşamın kalbi olarak gördü (Weber, 2001). Kentsel topluluk rekabeti ve resmi kontrolü temsil ederken kırsal bölge köylülüğün geleneksel uyumu ile ilişkilendirildi. Chicago Okulu üyeleri çalışmalarında kırsal topluluklardan neredeyse hiç bahsetmemektedirler. Oysa bugün kent sosyolojisinde gelinen noktada kent kır sürekliliği söz konusudur. Kentin nerede başladığı, köyü nerede bittiği belirsizdir, kırsaldan kentsele kentselden kırsala geçişler söz konusudur.
"Son yıllarda büyük kentlerden Ege ve Akdeniz kırsalına doğru bir nüfus hareketi olduğu gözlenmektedir. Öte yandan uzun zamandır nüfus kaybeden kırsal, bu nüfus değişimi karşısında oldukça savunmasızdır. Doğaya yakın olma ve daha basit bir yaşam isteği ile kırsala yerleșen kentliler aslında beraberlerinde kente dair bir bașka ifade ile orta sınıfa ait alışkanlıkları, beğenileri ve konforu da getirmektedirler. Kentten göç alan ve /veya turizm sektörünün geliştiği kırsal alanlarda tarımsal üretim yerini hizmet sektörüne bırakmaktadır." (Uysal-Başaran, 2017)

Kırsal bölgelerden kentlere göç, günümüzde kırsal alanlara göç şekline dönüşmüştür. Sadece kentsel bölgelerin çekiciliğinin azalması değil, aynı zamanda kırsalın daha yaşanabilir hale gelmesi neticesinde köylerin modernleşmesiyle, kentsel ile kırsal olan arasındaki açığın azaldığıdır. Keyder ve Yenal, Türkiye bağlamında süreci açılarken, kentlerin "çekiciliğinin" yanısıra köylerin 
iticiliğinin azalmasına da vurgu yapmak gerektiğini belirtmektedirler. Ayrıca yazarlara göre, kentten kırsal alanlara göç süreci ile ilgili olarak Türkiye'de yeniden köylüleşme sürecinden bahsetmek de mümkündür. (Keyder ve Yenal, 2015: 186-217)

Kentte ya da kırda soylulaştırma sürecinin benzer temel özellikleri vardır:

1- Yeni bir sermaye yatırımı

2- Daha yüksek bir gelir grubunun gelmesi

3- Fiziksel peyzajda değişim

4- Düşük gelir grubunun doğrudan ya da dolaylı bir biçimde yerinden edilmesi (Davidson ve Lees'den akt. Uysal- Başaran, 2017:37) "Lees, soylulaştırma süreci yaşamış olan yerleşimlerin yeniden bir üst gelir grubu tarafından ele geçirilmesini süper soylulaştırma olarak tanımlamaktadır. "(Uysal-Başaran, 2017:37)

"Yeni metropol gerçeği tüketim ve yaşayan biçimindeki tercihlerin/ değișimlerin etkisi ile, kentten izole, kentten uzakta, kapalı ve korunakl sitelerin oluştuğu kendi kendine yeten sinır/ kenar (edge) kentlerin oluştuğu, ancak bunun yanında yine kentten izole gettoların oluştuğu, kent merkezinin etkisini yitirdiği merkezsiz kentleri tanımlamaktadır. Bu süreçte yoğun nüfus hareketlerinin (konut iş merkezleri ve sanayi), kentin saçakları yönünde yer seçtiği görülmektedir." (Beauregard, 2008'den akt. Yenigül ve Çamur, 2013: 198-231)

Metropoliten kent saçaklarındaki yoğun nüfus hareketleri kentin saçaklarındaki yerleşimlerde özellikle kırsal yerleşimlerde nüfus artışına neden olmaktadır. Bu yerleşimlerdeki nüfus artışı kırsal nüfus artışı değil, eski kırsal yerleşimlerin göç alarak metropoliten kente katılması olayıdır. Counterurbanization olarak literatürde yer alan tersine göç, yani kırın kentleşmesi saçaklanmanın etkisiyle gelişen erişilebilirliğin kolay olduğu kentin yakın çevresinde gözlenmektedir. Ulaşım teknolojisindeki gelişmeler, özel araç sahipliğinin insanları hareketli kılması, kentin saçaklanma alanlarına olan talebi artırmıştır.

"20. yüzyılın son çeyreğinde etkisini daha da yoğun göstermeye bașlayan küreselleșme süreciyle birlikte kırsal alanlarda değişim ve dönüșüm devam etmiștir. Küreselleșme politikalarının, neoliberal politikaların ve özellikle kapitalist sistemin tüketim mantığının yerleșimlerin dönüșüm sürecinde etkili olduğu ve bu etkinin kırda kurduğu hakimiyet ile açıklanabileceği yönünde görüşler ortaya çıkmıştır. Bu süreçte kırsal alanlarda tarım dışı faaliyetlerin gelişmesiyle kırsal alanların içeriğinin değiștiği, üretenden çok tüketen bir kırsal alanla karşı karşıya kalındığı, tarım sektöründen hizmetler sektörüne doğru bir geçiş olduğu söylenebilir. Kırsal alanlar, küreselleșme ve yerelleșme söylemleriyle, bu yeni dünya düzeninde potansiyellerini öne çlkarabildikleri sürece gelișimini devam ettirebilmeye bașlamıș, kentler karşında cazibesini yeniden kazanmaya başlamıștır. Bu süreçle birlikte kırsal alanlar, tarım ve ormancllı̆ın başat olduğu ama bunun yanında turizm küçük ve orta ölçekte sanayinin ve el sanatları gibi diğer ekonomik faaliyetlerin de önemli olduğu, ekolojik açıdan değerli ve kentli insanlarla sürekli etkileșim halinde olan alanlar olarak gelişmeye devam etmiștir. Bu durum kırsal alanlarda farklı sektörlerin gelişmesi gereğini ortaya çıkarırken, sektörel gelişmelerle birlikte mekânsal gelişmelerin de gerekliliği yönündeki tartışmalara da neden olmuștur." (Davoudi ve Stead, 2003; Epstein, 2003; Costis, 2003; OECD, 2006; Noronha vd. 2006; Ulusal Kırsal Kalkınma Stratejisi, 2013'ten akt. Yenigül, 2017).

Kırsal alanda kentsel nüfus artışı, yeniden köylüleșme hareketi kavramını da gündeme getirmiștir. Yeniden köylüleşme hareketi kırsal alanlara kentlerden göç ve kırsalda demografik bir değişim ile nitelenmekte, bir yanı ile slow food hareketi olarak da görülebilmektedir (Çiftçi -Yeşiltuna, 2016: 73).

"Kırsal alanlarda tarım dışı sektörlerin gelişmesi ile artan istihdam ve bu istihdama yönelik konut ihtiyacının kırsal alanlarda temini ile kırdan kente göçün yönü kentten kıra olmak üzere tersine çevrilmiştir. Kentlerdeki yoğun nüfus birikimi ve beraberinde getirdiği sorunlarla kentsel alanda yaşamın zorlaşması ile gelişen günümüz popülist yaklaşımları ile doğayı öykünen yaşam biçimi 
kırsal alanlarda yaşama isteğine neden olmakta kırsal alanların içeriğinde dönüşüme neden olmaktadır. Özellikle orta ve üstü gelir ve kültür gruplarının kentlerden kaçma fırsatı olarak gördüğü kırsal alanlarda yaşama isteği bu yeni değişim sürecini hızlandırmıştır. Daha önceleri kırsal alanlarda yaşamın bir övünç kaynağı olarak algılanmadığı, yani kentte yaşam hayallerinin kurulduğu dönemden kırsal alanda yüksek yaşam kalitesi sunan konut ve çevresindeki yeni yaşam alanları ile kırsalın Prestij olarak algılandığı bir döneme geçilmiştir." Kırsal soylulaştırma literatürü, mekâna sonradan gelen üst-orta sınıfların, eğitim düzeyleri ve kentsoylu olmalarına bağlı diğer nitelikleri düşünüldüğ̈̈nde önemli olumlu katkılarının olabileceğini teslim eder. (Yenigül,2017,20)

Söke Doğanbey köyünde yapılan araştırmada kırsal alana göç edenlerin yerel halk ile ilişkileri şu şekilde değerlendirilmektedir: Domatia örneğinde, yeni yerleşimciler buranın tarihsel ve kültürel mirasının ayağa kaldırılması anlamında önemli katkılarda bulunmuş olsa da literatürün örneklendirdiği türde yerli halk ile soylulaştırıcılar arasında dayanıșma ve ekoloji temelli ortak mücadele deneyimlerine rastlanmamaktadır. Öyle ki, iki farklı kesimin bölgenin tanıtımına ve korunmasına ilişkin yaklaşımları oldukça farklıdır. Birbirine çok yakın ve birbiriyle sürekli etkileşim hâlinde olması beklenen iki mekânın gündelik yaşam pratiklerinde büyük bir uçurum olduğu söylenebilir. Eski Doğanbey Köyü'nün yeni sakinleri estetik ve pastoral bir köy fantezisi içerisinde yaşarken hemen birkaç kilometre ötede bildiğimiz anlamda bir köy hayatı sürmektedir. Bu iki köy farklı zamansal uzamlarda yaşar gibidir. Araştırma, iki köy arasındaki temassızlık hâlinin temel nedeninin sınıfsal ve kültürel farklılıklar olduğunu vurgulamaktadır. Kentten kıra gelen yerleşimcilerin kültürel ve sınıfsal özelliklerini kır ölçeğinde sürdürmeye devam ettikleri ve bu hibrit hâlin Yeni Doğanbey köylüleri ile diyaloglarını sınırladığı anlaşılmaktadır (Orhan ve Güneș, 2019: 8-38).

\begin{abstract}
"Kentlerin teknoloji, erişim ve ulaşım olanakları gibi katalizör etkisi gören etmenlerin de yardımıyla kırsal alana ve kırsal yerleşimlere doğru saçaklanarak genişlemesi, kırsal yerleşimlerin çözümlen (e)meyen sorunlarının üzerine kentsel baskıların da eklenmesi, yasalyönetsel değişiklikler ile kırsal yerleșimlerin kent statüsüne geçmesi sorunları daha da artırmaktadır. Kırın kendine özgü dokusu bu baskı altına girmekte ve kaybolmaya başlamaktadır. Bunun yanında 'kırsal soylulaștırma' olgusu; büyüme eğilimi sonucunda kentlerin çevrelerindeki kırsal karakterli alanları yutarak bu alanları etkileri altına almaya, bu alanlarda yapısal değişim ve dönüşüme de neden olmaktadır. Çalıșma ve yaşam koşullarını iyileștirmek isteyen, altyapı gibi ihtiyaca bağlı sorunlarıı çözmek isteyen kırsal yerleşimler 'kent gibi olma' durumu ile karşıl karşılyadır." (Çilingir ve Kut-Görgün, 2018: 139-151).
\end{abstract}

\title{
3 Kırsal Soylulaştırma Örneği Olarak Antalya Döșemealtı 3.1 Bölgenin Coğrafi Özellikleri
}

“Antalya kent merkezinin kuzeyinde yer alan Döşemealtı; Türkiye'nin en eski iskân yerlerinden biri olma özelliğine sahip, uzun süreli bir iskânın izlerini gösteren yaklaşı 11 metre kalınlığında arkeolojik ve jeolojik dolgusunun olduğu, Alt Paleolitik dönemden Geç Roma-Erken Bizans dönemine kadar uzun süreli bir iskânın izlerini taşıyan Karain Mağarası'nın yakınındaki ovada kurulmuş bir yerleşim yeridir." (Dünden bugüne Antalya, 2012, 253)

Bugünkü Döşemealtı yerleşim alanının oluşumunda Yenice Boğazı geçidi ve Döşeme Boğazı geçidi önemli rol oynamaktadır. Yenice Boğazı bölgeyi Batı yönünde bulunan yerleşim birimlerine (Korkuteli Elmalı Muğla ve Denizli) bağlamaktadır. Aynı zamanda Antalya yönüne de bağlamaktadır. Döșeme yolu ise Antalya kentini Hamit bölgesine (Isparta) bağlamaktadır. (Güçlü, 2006: 312 -345)

Yol güzergahlarında köprüler, eski zaman şehirleri önemlidir, üçüncü olarak yol kalıntıları önemlidir. Bugün Akdeniz bölgesinde Döşeme yolu, bazen de Gavur yolu adı verilen, büyük taşlarla döşenmiş, henüz apaçık belli olan parça parça yol kalıntılarıdır (Saraçoğlu, 1989: 652). Döşemealtı: taş döşeli yolun altındaki yer olarak tanımlanmaktadır. (Ercenk, 2010: 49) 
$\mathrm{Bu}$ durum bize Saraçoğlu'nun belirttiği üzere Döşemealtı olarak tanımlanan ilk coğrafi yerin Döşeme Boğazı yolunun düzlüğe açıldığı, su bakımından iyi durumda olan bölgede kurulmuş Ilıca, Camili, Ekşili, Killik, Karaveliler, Kovanlık, Kevşirler gibi görece eski yerleşimlerin bulunduğu kuzey doğu kesimi olduğunu kuşkuya yer bırakmayacak şekilde doğrulamaktadır.

Antalya'dan Kepezaltı'na (Kepez-altı), Kepezüstü'nden de Kırkgöz'e, Yenice boğazına ve kuzeydoğuda Kızıllı'ya doğru serilen, kademeleşmiş iki karakteristik, çok yeri taşlık ve fundalık, susuz, kalker șekillerinden üsttekine Kepezüstü denir. Y. Karaman'ın üstünde, Yenice boğazına doğru olan oldukça geniş ve çamlık alana Düzlerçamı denir ve burası üst sekinin ancak onda biri kadar yer kaplar. Üst sekinin Çubuk boğazı ağzına doğru olan yerlerine, bataklığa ve civarına Kırkgöz denirse de bu da küçük bir alan üzerine yayılmıştır. Lakin, Kırkgöz'ün kuzeydoğusunda, 15 km kadar eninde ve boyunda, düzlükleri ve bayırları da ihtiva eden, su bakımından fakir, içinde 10 kadar köy bulunan köşeye öteden beri Döșemealtı denir. Zira eski zamanlarda ve hatta yakın vakitlere kadar Antalya'dan Burdur'a doğru uzanan yol, şimdiki Çubuk boğazı yolundan değil, bu taraftan geçerdi ve yol büyük taşların döşenmesinden yapıldığı için, yola göre bu tarafın adı da Döşemealtı olarak kalmıștır, yani döşenmiş yolun alt tarafındaki alan demek (Saraçoğlu, 1989: 530). Adını aldığı "Döşemealtı Antik Yolu"nun alt kısmındaki ovada bulunan yerleşim yerleri ile o bölgeye verilen isimle anılan İlçenin İl merkezine uzaklığı yaklaşı 15 km'dir.

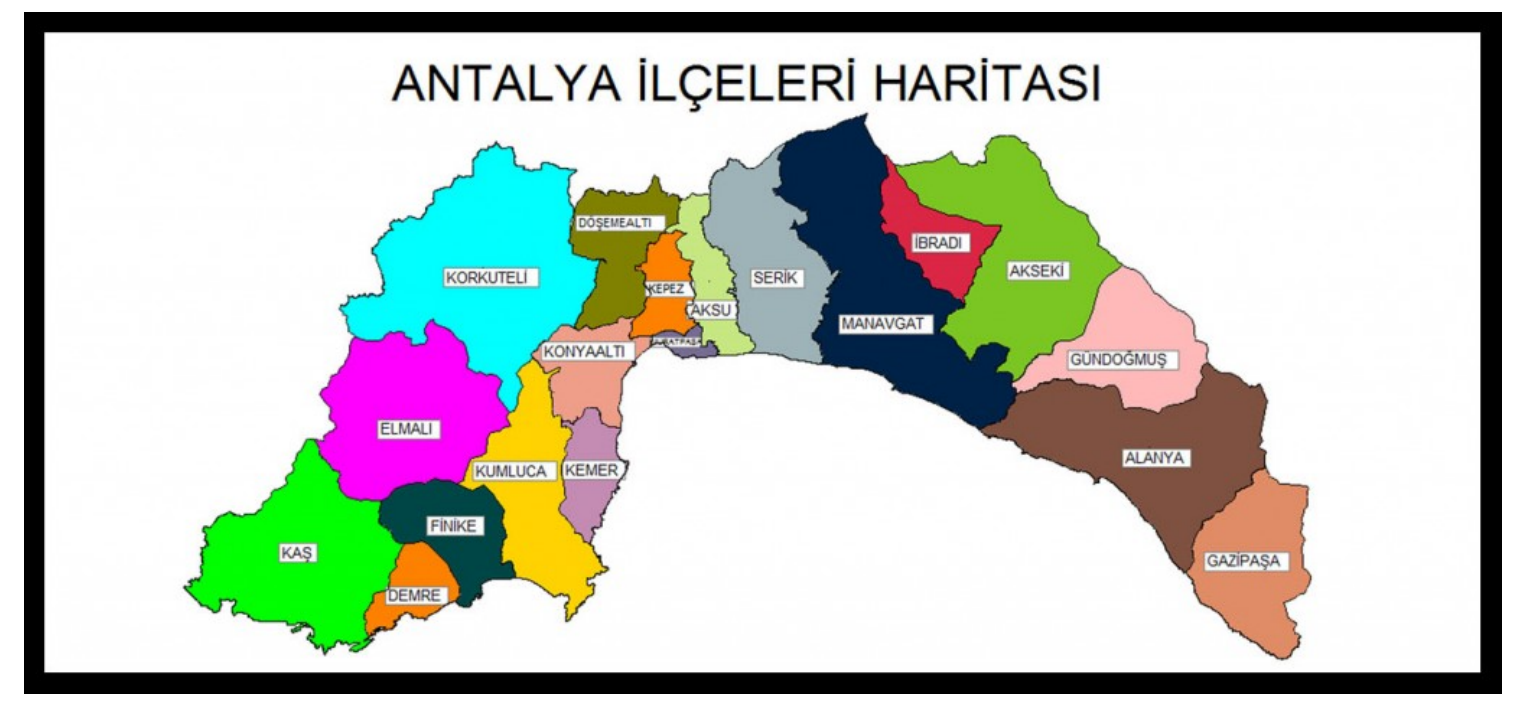

Şekil 1. Antalya ilçeleri haritası (Kaynak:

https://mavisehirantalya.wordpress.com/2017/05/04/antalyanin ilceleri/)

\subsection{Nüfus Özellikleri}

Döşemealtı ilçesi Antalya'nın merkez ilçeleri arasında (Muratpaşa, Kepez, Konyaaltı, Aksu ve Döșemealtı) en fazla yüzölçümüne sahip olmasına rağmen en az nüfusa sahip olan yerleşmesidir. Nüfusun \%50 si Yeniköy, Çıplaklı, Bahçeyaka, Yeşilbayır mahallelerinde yaşamaktadır. Diğer mahallelerin nüfusları $0-5000$ arasında değişmektedir. Kapladığı alan 687 kilometrekare, nüfus yoğunluğu kilometre kareye 80.7 kişidir (Kapan, 2018: 52-56).

Döşemealtı nüfusu 2020 yllına göre 69.300'dür.Bu nüfus, 35.372 erkek ve 33.928 kadından oluşmaktadır. Yüzde olarak ise: \%51,04 erkek, \%48,96 kadındır (TÜíK, 2020).

Döşemealtı Kaymakamlı̆ı sayfasında 32 mahalle olduğu belirtilmekte ve Döșemealtı Belediyesi resmi sayfasında mahalle muhtarlarının belirtildiği tabloda 32 mahalle isimleriyle belirtilmektedir: Ahırtaş, Akkoç, Altınkale, Aşağıoba, Ayanlar, Bademağacı, Bahçeyaka, Bıyıklı, Camili, Çığlık, Çıplaklı, 
Dağbeli, Dereli, Düzlerçamı, Ekşili, Ilıcaköy, Karaman, Karataş, Karaveliler, Kevşirler, Killik, Kovanlık, Kömürcüler, Nebiler, Orta, Selimiye, Tomalar, Yalınlı, Yağca, Yeniköy, Yeşilbayır.

\begin{tabular}{|l|l|l|l|}
\hline Yll & Döşemealtı nüfusu & Erkek & Kadın \\
\hline 2008 & 40637 & 20461 & 20176 \\
\hline 2009 & 40555 & 20414 & 20141 \\
\hline 2010 & 42433 & 23341 & 21092 \\
\hline 2011 & 44272 & 22313 & 21959 \\
\hline 2012 & 47497 & 24415 & 23082 \\
\hline 2013 & 52013 & 26678 & 25335 \\
\hline 2014 & 53554 & 27412 & 26142 \\
\hline 2015 & 55462 & 28497 & 26695 \\
\hline 2016 & 58451 & 30080 & 28371 \\
\hline 2017 & 59948 & 30789 & 29159 \\
\hline 2018 & 63186 & 32288 & 30898 \\
\hline 2019 & 65794 & 33610 & 32184 \\
\hline 2020 & 69300 & & \\
\hline
\end{tabular}

Tablo 1. Yıllara Göre Döşemealtı Nüfusu

\begin{tabular}{|l|l|l|l|l|l|l|l|l|l|}
\hline Mahalle & $\mathbf{2 0 1 2}$ & $\mathbf{2 0 1 3}$ & $\mathbf{2 0 1 4}$ & $\mathbf{2 0 1 5}$ & $\mathbf{2 0 1 6}$ & $\mathbf{2 0 1 7}$ & $\mathbf{2 0 1 8}$ & $\mathbf{2 0 1 9}$ & $\mathbf{2 0 2 0}$ \\
\hline Yeniköy & 9819 & 10799 & 11724 & 12507 & 13534 & 14137 & 14837 & 15832 & 17073 \\
\hline Bahçeyaka & 4678 & 5253 & 5740 & 6076 & 6918 & 7483 & 8157 & 8853 & 9679 \\
\hline Çplaklı & 4375 & 5883 & 6020 & 6161 & 6276 & 6060 & 6191 & 6259 & 6449 \\
\hline Yeşilbayır & 3718 & 4390 & 4230 & 4588 & 4913 & 4958 & 5183 & 5725 & 5972 \\
\hline Altınkale & 2081 & 2277 & 2451 & 2499 & 2754 & 3016 & 3609 & 4081 & 4855 \\
\hline Kömürcüler & & 2630 & 2663 & 3012 & 3195 & 3359 & 3122 & 3344 & 3253 \\
\hline Dağbeli & & 1970 & 1835 & 1784 & 1792 & 1711 & 1934 & 1832 & 1768 \\
\hline Nebiler & 1311 & 1395 & 1411 & 1435 & 1497 & 1527 & 1548 & 1568 & 1644 \\
\hline
\end{tabular}




\begin{tabular}{|c|c|c|c|c|c|c|c|c|c|}
\hline Yalınlı & 1134 & 1232 & 1232 & 1246 & 1294 & 1351 & 1386 & 1397 & 1463 \\
\hline Kovanlık & & 1264 & 1325 & 1270 & 1276 & 1272 & 1473 & 1377 & 1353 \\
\hline Düzlerçamı & 1056 & 1107 & 1298 & 1154 & 1205 & 1260 & 1330 & 1348 & 1389 \\
\hline Yağca & & 1238 & 1257 & 1310 & 1320 & 1319 & 1414 & 1338 & 1344 \\
\hline Bademağacı & & 1481 & 1399 & 1343 & 1293 & 1311 & 1332 & 1250 & 1265 \\
\hline Tomalar & 864 & 894 & 1023 & 1041 & 1083 & 1153 & 1169 & 1245 & 1324 \\
\hline Karaveliler & & 1194 & 1180 & 1124 & 1114 & 1094 & 1106 & 1072 & 1048 \\
\hline Orta & 804 & 864 & 879 & 904 & 927 & 974 & 1046 & 1021 & 1035 \\
\hline Killik & & 1049 & 1025 & 1000 & 995 & 976 & 991 & 995 & 1003 \\
\hline Karataș & & 811 & 852 & 878 & 899 & 874 & 915 & 926 & 955 \\
\hline Ekşili & & 863 & 848 & 823 & 836 & 827 & 870 & 859 & 881 \\
\hline Çı̆̆llk & 808 & 803 & 802 & 788 & 811 & 785 & 800 & 786 & 806 \\
\hline Ayanlar & & 675 & 699 & 697 & 684 & 690 & 705 & 711 & 726 \\
\hline Ilıcaköy & & 540 & 549 & 572 & 578 & 588 & 698 & 668 & 696 \\
\hline Aydınlar & & 627 & 635 & 626 & 649 & 645 & 639 & 648 & 641 \\
\hline Karaman & 492 & 553 & 524 & 522 & 529 & 545 & 560 & 555 & 595 \\
\hline Camili & 672 & 471 & 440 & 442 & 428 & 421 & 453 & 410 & 406 \\
\hline Ahırtaş & & 517 & 474 & 443 & 425 & 402 & 405 & 400 & 385 \\
\hline Aşağıoba & & 325 & 343 & 348 & 346 & 345 & 348 & 361 & 362 \\
\hline Akkoç & & 336 & 327 & 313 & 317 & 304 & 300 & 303 & 293 \\
\hline Kevşirler & & 207 & 192 & 196 & 189 & 198 & 252 & 227 & 224 \\
\hline Dereli & & 146 & 153 & 148 & 161 & 160 & 164 & 160 & 166 \\
\hline Biyıklı & & 162 & 165 & 153 & 155 & 135 & 181 & 159 & 172 \\
\hline Selimiye & & 42 & 44 & 44 & 47 & 55 & 59 & 56 & 49 \\
\hline
\end{tabular}

Tablo 2. Döşemealtı Mahallelerinin Yıllara Göre Nüfusu 


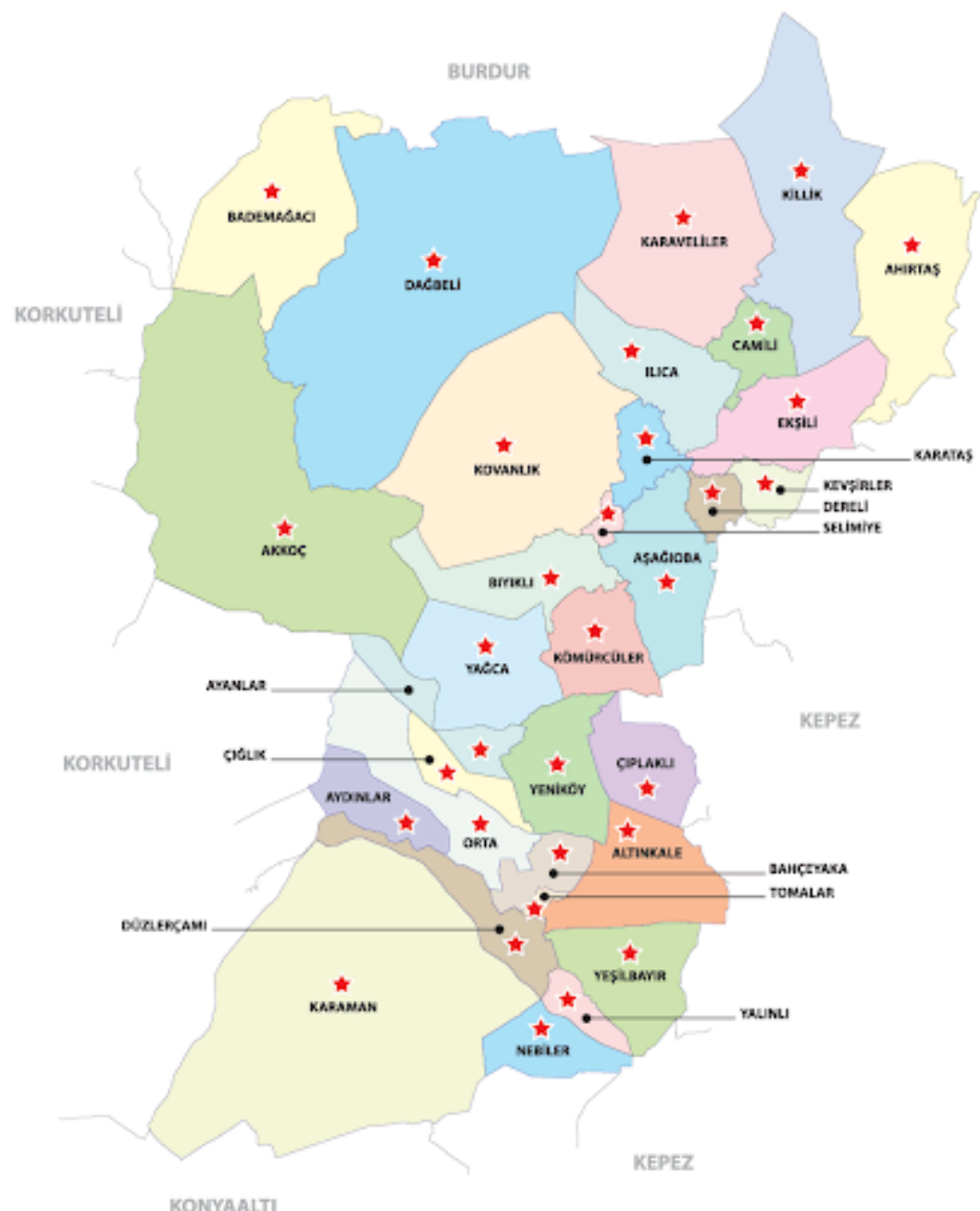

Şekil 2. Döşemealtı mahalleleri (Döşemealtı Belediyesi, 2016)

\subsection{Bölgenin Tarihi ve İdari Özellikleri}

"Yakın dönemde 1934 yılından beri ikamet edilen ve o yıllarda Kırkgöz-Yeniköy olarak da bilinen bu bölgenin, 1934 yılında zamanın Valisi Haşim IŞCAN tarafından buradaki iskân evlerine Kıbrıs'tan getirilen 60 kadar Türk vatandaşı ailelerin, Korkuteli Kızılcadağ mevkiinden gelen ailelerin ve çevre illerden gelen yörüklerin yerleşmesiyle "YENIKÖY" adı ile bir köyün meydana geldiği, aynı yıl içerisinde de Yeniköy Nahiyesi olarak teșkilatlandığı anlaşılmaktadır. 17 Aralık 1977 yılında "DÖŞEMEALTI" adı ile Belde olan bu yerleșim merkezinin, 5747 Sayılı Kanun'la İlçe statüsüne kavuşturularak, 2008 yılının ikinci yarısından itibaren, Antalya'nın 19 İlçesinden biri olarak "Döşemealtı İlçesi" adı ile hizmet vermeye başladığı görülmektedir." (Sarı, Demirkaya, Kurt ve Çeçen, 2012; 266).

“Anadolu Selçuklu Devletinin yıkılması ile 1260 yıllarında bölgeye hâkim olan Hamidoğulları zamanında bölgeye yerleșmeye bașlayan Karakoyunlu ve Sarıkeçili gibi Yörük așiretleri yerleşim birimlerini oluşturmuşlardır. Antalya ve çevresinin 1390 yılında Osmanlı hâkimiyetine girmesi yöreyi Teke sancağı adı altında Konya' ya bağlamıştır.1934 yılında Korkuteli- Kızılcadăg bölgesinden gelen ailelerin yerleştirildikleri ve Kırkgöz-Yeniköy adı 
verilen köye Kıbrıs' tan gelen aileler ve göçebe olarak yaşayan Yörükler de katılarak, bugünkü Döşemealtı ilçesinin ilk halk tabanı oluşmaya başlamıştır. Döșemealtı adının tarihçesi ise şöyledir. Antik çağda sahildeki Pamfilya kentleri ile iç kesimlerdeki Pisidia kentlerinin birbirine bağlayan yollardan birisi olan ilçe merkezine $9 \mathrm{~km}$. uzaklıkta bulunan Derbent Boğazındaki döşeme taş yolundan almıştır. Bizans, Selçuklu, Osmanlı Dönemlerinde de faal olan döşeme yol yakın zamana kadar yörükler tarafindan göç yolu olarak da kullanılmakta idi. Dösseme taşlardan oluşan ve 4 metre genişliğindeki yol bu bölgenin Dössemealtı olarak isimlendirilmesine neden olmuştur. Son olarak, 22 Mart 2008 tarihinde yürürlüğe giren 5747 sayılı, 'Büyükşehir Belediyesi Sinırları İçerisinde İlçe kurulması ve Bazı Kanunlarda Değișiklik yapılması Hakkında Kanun ' ile bölgedeki Yeșilbayır, Düzlerçamı ve Çığlık Belediyelerinin 29 Mart 2009 Yerel Seçimleri ile tüzel kișilikleri son bulmuș ve mahalleleri ile Döșemealtı Belediyesine katılarak toplam 14 mahalleden oluşan Döşemealtı İlçe Merkezi oluşmuştur."

Başlangıçta Döşeme boğazının düzlüğe açıldığı, içinde sınırlı sayıda köy olan küçük bir bölgeden ibaret Döşemealtı'nın ilçe olmadan önceki bağlı kasaba- köy durumu şöyledir:

Çı̆̆lık, Düzlerçamı (Yukarı Karaman ve Nebiler'in birleştirilmesiyle), Ekşili, Karaveliler, Yeniköy ve Yeşilbayır olmak üzere 6 belediye örgütü; Ahırtaș, Killik, Camili, Ilıca, Kovanlık, Dereli, Kevşirler, Karataş, Selimiye, Kızıllı, Aşağıoba, Bıyıklı, Yağca, Kömürcüler, Çıplaklı, Başköy, Odabaşı, Kirişçiler, Çamlıca (Hotuşlar) olmak üzere toplam 19 köy bulunmaktaydı. Belediye ve köy statüsündeki yerleşme sayısı toplamı 25 idi.

1932 yılında yayınlanan Cumhuriyet'in Onuncu Yılının Eșiğinde Antalya Coğrafyası adlı eserde Antalya'nın idari durumu başlıklı tabloda 32 köyü olan Döşemealtı nahiyesinden sözedilmektedir. (Güçlü,2018:34) 1 Haziran 1970 tarihi itibari ile Antalya vilayetinin 11 ilçesi, 22 bucağı, 608 köyü vardır bucakların 6'sı merkez ilçeye bağlıdır, köylerin ise 13'ü merkeze 22'si Aksu (Macun)'a, 23'ü Döşemealtı Yeniköy'e ve 6'sı Kemer bucağına bağlıdır (Güçlü, 1997: 37).

Döşemealtı Kaymakamlığı sitesinde de yukarıdaki bilgileri genişleten şu açıklama yer almaktadır: 2008 yılı başında Vali Alaaddin Yüksel'in "Antalya'nın kuzeyinde bir ilçe oluşturulması gerekliliğine ilişkin" açıklaması basında yer aldı. Vali Yüksel açıklamasında "kent kuzeye büyüyor, il merkezinden kuzeydeki bölgeye hâkim olmak yönetmek zorlaşıyor. Orası Kaymakamlık statüsüne kavuşturulmalı. Döșemealtı merkezde yeni bir ilçe oluşturulması konusunda gerekli başvuruların yapıldığını" açıklıyordu. Bu açıklamanın ardından çıkartılan bir yasa ile Merkezi Yeniköy olmak üzere Döşemealtı adı ile yeni bir ilçe oluşturularak Yeşilbayır, Çığlık, Düzlerçamı (Yukarı Karaman ve Nebiler), belediyeleri yeni ilçenin mahalleri haline getirilirken Çubuk Boğazı ötesindeki Dağbeli ve Bademağacı ile Ekşili, Karaveliler beldeleri yeni ilçeye bağlandı. Bu oluşumla birlikte Döşemealtı'nın yerleşim yapısı değişti.

"28 Mart 2008'de yürürlüğe giren 5747 sayılı kanun ile Antalya'nın 5 merkez ilçesinden biri olan Döşemealtı'nın ilçe merkezi ile Antalya'nın il merkezi arası 20 kilometredir. Önceleri adını Düden Şelalesi'ni besleyen Kırkgöz gölünden almış, ardından uzun yıllar kışlak olarak Kırkgöz'ü, yaylak olarak da Korkuteli Kızılcadağ mevkiini kullanan Yörük așiretlerinin 1934 yılında iskân edilmesi ile Kırkgöz -Yeniköy olarak kurulmuștur. 1940'lara doğru dönemin Antalya Valisi Hașim İșcan tarafindan 60 adet iskân evi yaptırılmıș ve bu konutlara Kıbris'tan gelen aileler yerleștirilmiștir. Bölgede göçebe olarak yaşayan diğer Yörüklerin aşiretlerinin de yerleșik düzene geçmesi ile Kırkgöz- Yeniköy genişleyen bir köy olmuș, böylelikle Yörükler ve Kıbrıslı aileler Döșemealtı'nın kurucu halk tabanını olușturmuștur. 1970'li yılların bașında Yeniköy Nahiye Müdürlüğü 17 Aralık 1977 yılında 2711 nüfusa ulaştığından belediye teșkilatı kurulmuş ve Kırkgöz-Yeniköy, "Döșemealtı Belediyesi" ünvanını almıștır." (Http://doseme alti.gov.tr/ilçe-tarihçemiz).

“Antalya Büyükșehir Belediyesi'nin Tarihsel Gelişimi Antalya Belediyesi 1984 yılında yürürlüğe giren 3030 sayılı yasa'nın dayanak olușturduğu yapılanma içerisinde, kentin yönetim statüsünün değiștiği 1993 yılı, yeni bir sürecin başlangıcı olmuş, 504 sayılı Kanun Hükmünde Kararname ile Antalya Belediyesi, büyükșehir belediyesi statüsü almış ve Büyükșehir Belediyesi sınırları içerisinde Muratpaşa, Kepez ve Konyaaltı olmak üzere üç alt kademe belediyesi kurulmuştur. 5216 sayılı Yasa öncesinde, Muratpaşa, Kepez ve Konyaaltı Belediyelerinin 


\begin{abstract}
olușturduğu büyükșehir belediyesi alanı 420 km2 bir sahayı kapsarken, 5216 Yasa sonrasında yasa'nın öngördüğ̈̈ düzenleme ile 1381 km2 çıkmıştır. (Valilik binasını merkez kabul eden ve yarıçap $20 \mathrm{~km}$ olan daire ile tanımlanan) yeni sınırla, Muratpaşa, Kepez ve Konyaaltı Belediyelerine, Aksu, Beldibi, Çalkaya, Çı̆̆glık, Doyran, Döșemealtı, Düzlerçamı, Pınarlı, Varsak, Yeşilbayır ve Yurtpınar Belediyeleri de eklenmiştir .5747 sayılı Büyükşehir Belediyesi Sınırları İçerisinde İlçe Kurulması Ve Bazı Kanunlarda Değişiklik Yapılması Hakkında Kanunla Konyaaltı, Kepez, Döşemealtı, Aksu ve Muratpaşa ilçe belediyesi olmak üzere 5 ilçe belediyesi kurulmuştur .6360 sayılı kanunla 2014 tarihinde yapılan Mahalli İdareler Genel Seçimlerinden sonra Antalya ili mülki sınır kabul edilmiș ve il içerisinde kalan toplam (20.749 km2) 19 ilçe Antalya Büyükşehir Belediyesi'nin İlçe belediyeleri olmuştur. Büyükşehir sınırı yaklaşık bir önceki sınırın 150 katı büyüklüğüne ulaşmıştır.” (Hansu, 2015; 25, 85- 92).
\end{abstract}

\title{
3.4 Yörük Obalarının Kışlağından Köy Olma Sürecine
}

Döşemealtı bölgesinde kışlayan Yörük obaları için yerleşmenin miladı,1941 yılının 18 Şubat günü Milletvekili Rasih Kaplan, Vali Haşim İșcan ve il bürokratlarının Yeniköy'de yaptıkları inceleme gezisi ve ardından halkın katılımıyla yapılan toplantıdır. O gün, Kırkgöz-Antalya karayolunun doğusundaki Başından Yoklu (Başköy), Kirişçiler, Çıplaklı, Odabaşı gibi göçebe mührü olan Yeni Osmanlı asıllarının ve yakın batısında kışlayan Kızılcadağ çevresindeki Yalınlı, Nebiler, Yukarı Karaman, Piyadın köylerinin muhtarları ile oymak ve köy ileri gelenlerinin Vali, milletvekilleri, İl bölge ve idare müdürlerinin önünde "yerleșme isteklerini" dile getirmeleri ile o zamana kadar kışlak ağırlıklı olarak kullanılan Döşemealtı düzlüğünün orta ve güney kesimleri köyleşme sürecine girecekti.(Ercenk, 2010: 158)

O yıllarda bölgeyi gezen Vala Nurettin (Va-Nu) 1944 yılında yayınladığı Antalya kitabında Antalya'dan Burdur'a giden yol üzerinde yapılanma halinde 2 yepyeni köy gördüğünü yazar. Biri Kıbrıs'tan göçen Türklere hükümetimizin hediye ettiği muntazam evlerden mürekkep (oluşan) kiremitli damları, odalarında dokuma tezgâhları, önünde yemiş bahçeleri Cumhuriyet meydanında öğretmenli ve eğitmenli koskoca okul, nalbant, bakkal vesair dükkanları... Bir de halk odası. Vala Nurettin'in yukarıdaki satırlarda anlattığı yer Döșemealtı ilçesinin merkezi bugünkü Yeniköy'dür. Kitabında görüşlerini şöyle belirtir:

Antalya'dan Burdur'a giden yol üzerinde yapılma halinde iki yepyeni köy gördüm. Biri Kıbrıs'tan göçen Türklere hükümetimizin hediye ettiği muntazam evlerden mürekkep: kiremitli damları, odalarında dokuma tezgâhları önlerinde yemiş bahçeleri köyün Cumhuriyet meydanında öğretmenli ve eğitmenli koskoca okul, resmi dairecikler. Nahiye müdürünün ve karakol komutanının evleri. Nalbandı, bakkal vesair dükkanları. Bir de halkodası ki halkevinin küçüğüdür. Türkiye'de ilk defa olarak bu tipte burası yapılmıștı. Sahnesi, temsil salonu, sıhhi yardım kısmı ile cümlesi pek makul bir planla bina ediliyor. Kıbrıslar köyünün biraz daha berisinde ve aynı yol üzerinde bir de Göçebeler köyü yapılmış, bitmiş. Evler tamam. Sadece yukarıda bahsettiğim umumi müesseseler tamamlanmamış. Köylülüğe terfi edecek olan şimdiki göçebeler "imece" dedikleri elbirliği usulü ile ve ustaların nezareti altında müstakbel köylerini tamamlamak üzere çalışıyor. Yeni hükümet binaları: Gündoğmuş ve Elmalı kazalarında ve Döșemealtı nahiye Merkezi Kırkgöz köyünde olmak üzere 3 yeni hükümet binası yapılmıştır. (Va-Nu, 1944: 22). 


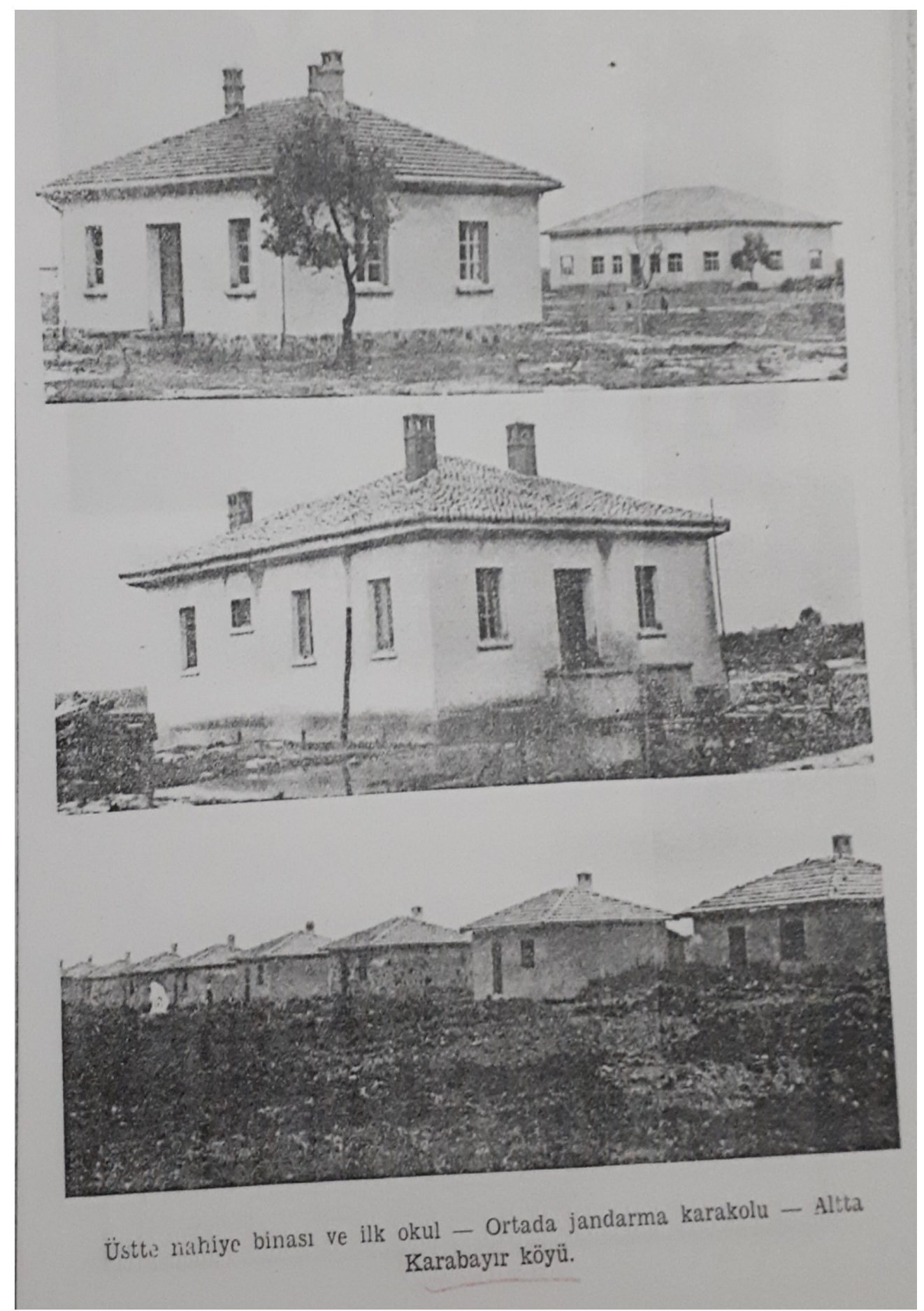

Şekil 3: 1940’larda Döşemealtı (Kaynak: Va-La Nurettin, Antalya İkinci Dünya Harbi İçinde Nasıl Güzelleşebildi? Kenan Matbaası İstanbul 1944: 22)

Hilmi Ziya Ülken, Nurettin Şazi Kösemihal ve Cahit Tanyol, 1950 yılında yayınladıkları, Döşemealtı köylerinden Karataş Köyü hakkındaki monografik çalışmalarında şunları belirtmektedirler: 
Karataș, Antalya vilayetinin Dössemealtı nahiyesine bağlı köylerdendir. Köy," Döşemealtı" bölgesinin tam ortasındadır. Dağda Tekeoğulları zamanından beri bir döşeme yolu olduğu için bölge bu adla anılmaktadır. Doğuda Karaöz, kuzeyde Melli, batıda dağlar, güney-doğuda da İlyas alanı bulunmaktadır. Bu bölgenin kuzey, batı ve kuzey batı tarafları tamamen dağlarla çevrili, güney ve güney-batı tarafları da geniş bir ovaya açılmaktadır. Bölge Antalya ovasının kuzeye bakan dağ yamaçlarındadır. Karataş köyü, eskiden yerleşmiş Yörük köyleriyle çevrili ve her birine hemen hemen müsavi mesafede bir Muhacir köyüdür. Hububat ekimi yapılan köy, yörük köylerinden sosyal bakımdan farklıdır. Kadınları tarlada çalışmaz. Evleri muntazam ve temizdir. Civar köyler yörük ve hayvancılıkla uğraşırken, bu köy muhacir ve ziraatçıdır. Yörük köylere mayalı ekmek yapmasını öğretmiş, yerli saban yerine muhacir sabanı kullanmışlardır. Muhacirler arasında evlenmeler tercih edilmektedir (Ülken, Kösemihal, Tanyol,1950: 85-103).

Tahsin Özdemir, 1943-44 tarihli Türk Akdeniz Dergisinde Karataş köyüne ilişkin şunları yazmaktadır: Antalya ovasını baştanbaşa sulayan ve Antalya su şehri adını veren Kırkgöz suyunu geçtikten sonra buradaki karakolun önünde otomobilden iniyor ve bindiğimiz tek atlı bir araba ile Döşemealtı bölgesine doğru yol alıyoruz. Döșemealtı denilen saha 15-20 köyden ibaret, oldukça geniş bir bölgedir. 14 köyünde eğitmenli okul vardır. Arabamız Karataş köyünün önünde durdu. Köyün en yaşlısı ile konuşuyoruz. 63 sene evvel Mora Yenişehrinden gelen göçmenlerle kurulan bu köyün, o tarihten beri çocuklarını okutmak imkanını bulamadıklarını, hatta ilk iskanlarında 60 hane olan köyün 32 haneden ibaret kalmasının sebepleri arasında okulsuzluğun aranması lazım geldiğini yana yakıla anlatıyor. Dereli köyüne geliyoruz. Köyün en müsait yerine kurulan okul binası. Burası da 60 sene evvel yerleştirilmiş Yenişehir Türkleri ile kurulmuş bir köy. Camili ve Kovanlık köylerini ziyaret ediyoruz. Bu köylerde de eğitmenli okulların planları tatbik edilmiş ve bitirilmiştir (Vilayetimiz Aksu Köy Enstitüsünün üç devrede yetiştirdiği 170 öğretmenden bir kısmının faaliyetlerini yakından görmek için yapılan seyahat) (Özdemir,1943-44: 7-10).

Kıbrıs'tan gelenler tarım; yörükler, hayvancılık yapmaktadır.

"Döșemealtı, adını antik çağda Pamfilya kentleri ile Pisidia kentlerini birbirine bağlayan yollardan birisi olan Derbent boğazındaki günümüzde varlığını koruyan döșeme taş yolundan almıştır. Bizans Selçuklu Osmanlı dönemlerinde işlevini sürdürmüş olan döşeme yol, yakın zamana kadar yörükler tarafından göç yolu olarak kullanılmıştır. Döşeme taşlardan oluşan bu yol Döşemealtı platosuna adını vermiş olup 4 metre genişliğindedir. Bu nedenle yöre halkı "döşeme” yolun geçtiği boğazı "Döşeme Boğazı", yolun altında kalan düzlüğü Döșemealtı olarak adlandırmıştır" (dosemealti.bel.tr).

Döşemealtı ilçesi ve çevresi, zamanında kış aylarında farklı birçok yörük obasına kışlak olarak ev sahipliği yapmıştır. Bunlar arasında yer alan Karahacılı aşireti de Döşemealtı Yeniköy'e kendi kışlaklarına 1934 'te iskân olmuştur.

Döşemealtı'nda meskun Yörük aşiretlerinin başlıcaları: Emirler, Karahacılı, Karakoyunlu, Karamanlı, Karatekeli, Karavelili, Kızıllı, Kömürcü, Sarıkeçili, Töngüşlü, Yeni Osmanlıdır. (Ak 2015: 20-83'ten aktaran Mehmet Emre Çelik, 2018).

Döșemealtı'nda Kırkgöz Han, Termessos Antik Kenti, Dağbeli Ariassos Antik Şehri, Evdir Han bulunmaktadır. Yeniköy, Kovanlık, Camili'de halıcılık yapılmaktadır.

Bugün kırsal özelliklerini yitirme sürecinde olan Döşemealtı köylerinde kentleşme öncesi temel iş güç ve üretim uğraşları şöyle sıralanabilir:

Ahırtaş; otçuluk, salep, kekik, adaçayı, ketre, keçi, koyun,

Killik; meyve, zeytin, akdarı, üzüm, buğday, arpa, keçi, zanaatkarlık,

Karaveliler; üzüm, pekmez, meyve, incir, akdarı, zeytin, zeytinyağı, bal, dokuma, menevrek (şayak), nakliye işleri, koyun, büyükbaş hayvan, 
Camili; keçi, büyükbaş hayvan, meyve, zeytinyağı, zeytin, menevrek, çeşitli dokuma, sebze, akdarı, zanaat, nakliye işleri,

Ilıca; koyun, üzüm, pekmez, pamuk, tahıl, akdarı, bal ve Ilıca gölü çevresinde yapılan su ve kara avcllığ,

Kovanlık; halı, üzüm, pekmez, buğday, arpa, saman, pamuk, keçi, büyükbaş hayvan, bal, balmumu, kovan üretimi, zanaat ve nakliye işleri,

Ekşili; keçi, sebze, meyve, incir, nar, bağ, değirmen, zanaat, nakliye işleri,

Kızıllı; palamut, keçi, büyükbaş hayvan, tahıl,

Aşağıoba; koyun, keçi, halı, tahıl, saman,

Kevşirler; koyun, büyükbaş hayvancılık, tahıl, taşıma işleri, halıcılık,

Bıyıklı; büyükbaş hayvan, özellikle manda, koyun, keçi, tahıl, çeltik, pamuk, değirmencilik,

Kömürcüler; koyun, keçi, büyükbaş hayvan, kireç ve kömür yakma, deve ile yük taşımacllığı,

Yağca; keçi, büyükbaş hayvan, meyve, tahıl, pamuk,

Çığlık; keçi, koyun, büyükbaş hayvan, tahıl, pamuk, susam, mısır, zeytin, kömür yakma,

Yeniköy; kuruluşunu izleyen yllardan itibaren hem idari hem de ekonomik anlamda Döşemealtı'nın merkezi durumuna gelmişti. Tarımda kullanılan motorlu araçların artması ile Yeniköy, bakım, tamir ve ikmal yeri özelliği kazanmıştı. Hizmet ve ticaret gelişmiști.

Karataș, Selimiye (Karadon), Dereli gibi muhacir köyleri, büyükbaş hayvan, koyun, bağcllık, üzüm, pekmez, tahıl, susam, at arabası ile taşımacılık, çevre çiftliklerde ırgatlık yaparak geçinirdi. Döşemealtı'nın hemen bütün köylerinde susam yetiştirilir ve Antalya'da tahin imalatçılarına ve susam değirmenlerine satılırdı.

Çıplaklı, Başköy, Karabayır, Yalınlı, Nebiler, Kirişçiler, Yukarı Karaman, Odabaşı, Hotuşlar gibi yerleşmeler, hayvancılık, zeytincilik, kömür yakma, yakacak kök çıkarma, deve ile nakliyecilik, ağaç kesim işleri, orman işçiliği, pamuk yetiştiriciliği gibi işlerle uğraşıyorlardı.

Camili, Kovanlık, Killik gibi köylerde ipekböcekçiliği de yapılmıştı (Ercenk, 2010: 81-82).

\subsection{Döșemealtı'yla İlgili Demografik Veriler Işığında Gözlemler}

Tarihsel ve demografik verilere bakıldığında 2000'lere kadar köy karakteri gösteren Döşemealtı bölgesi 2000'lerden sonra heterojen bir nüfus yapısı arz etmeye başlamıştır.

Kırdaki soylulaştırma, kentsel alışkanlıkların köy ölçeğine taşıma girişimi olarak görülmektedir. Burada kırsal doğa, önemli belirleyicidir. Döşemealtı köylerini yerleşmek için seçen kentli bireyler, burada doğayı yeni bir yaşam modeli olarak düşünmektedirler. Köy mekânı, farklı sınıftan kullanıcılar tarafından deneyimlenmekte, kullanılmakta ve metalaştırılmaktadır.

Bölgedeki heterojen nüfusu şöyle kategorize edebiliriz:

1)Köylerde yerleşik tarım ve hayvancılık ile geçimini sağlayan yerli nüfus,

2)Köylerde yerleşik, esnaf ve zanaatkarlık ile geçimini sağlayan yerli nüfus,

3)Köylerde esnaf ve zanaatkarlık ile uğraşan farklı yerleşim birimlerinden göç etmiş nüfus,

4)Köylere yerleșen ve mülkiyet edinerek (müstakil ev, güvenlikli konut siteleri, apartman dairesi, arsa, bahçe, tarla, toplu konut idaresi konutları vb.) burada temelli yerleșen emekli nüfus ve çalışan kentsel orta sinif, 
5)Köylerde mülkiyet edinip yılın belli dönemlerini burada geçiren kentte yerleşik nüfus, (İkinci Konut Sakinleri)

6)Yurtdışında çalışıp burada da mülk edinen ve daimî veya belli dönemlerde köylerde yaşayan nüfus,

7)Antalya Döșemealtı Organize Sanayi Bölgesi, banka, belediye, okul, hastane gibi kamu ve özel sektör kurumlarında çalışan ve eğitim nedeniyle (Özel üniversite ve lise dengi okullar) bu bölgede yaşayan nüfus. (Bu kategorileştirme,2000 yılından beri bu bölgede yaşayan bir sosyolog olarak tarafımdan yapılan gözlemlere dayalı olarak gerçekleştirilmiştir).

Döşemealtı'ndaki mahalleler de sosyo-ekonomik açıdan farklılıklar göstermektedir. İlçe merkezi olarak Yeniköy, idari kurumların, kamu ve özel sektör kuruluşlarının bulunduğu, Cuma günleri kurulan büyük bir pazar yerine sahip, çok katlı konutların yükseldiği, en fazla nüfusa sahip modern bir kent görünümündedir. Yeşilbayır, Altınkale, Bahçeyaka ve Çıplaklı diğer yoğun nüfuslu yerleşimlerdir. Bu mahallelerde müstakil konutlar bulunmaktadır. Diğer mahalleler göreli olarak daha az nüfuslu, kırsal karakteri olan, tarım ve hayvancılı̆̆ın yapıldığı, doğa ve sessizlik talep eden kentlilerin de tercih ettiği mahallelerdir. Hemen hemen tüm mahallelerde Pazar yerleri bulunmakta, olmayan yerlerdeki mahalle sakinlerinin ise belediye araçlarıyla merkeze ulaşımı sağlanmaktadır.

Döşemealtı bölgesinde yer alan köylerde mülkiyet el değiştirmiştir. Çok çeşitli konut biçimleri ve buna bağlı yaşam tarzları söz konusudur bölgede. Doğal mimarisi ile köy evleri, tarla ve ahırları, müstakil villalar, çok katlı binalar, lüks güvenlikli konut siteleri, toplu konutlar bölgedeki heterojenliği gözler önüne sermektedir. Ayrıca bölgede imarlı arsa ve ayrıca her türlü konut satışı ile iştigal eden çok sayıda emlak komisyoncusunun olması da bölgeye talebin her geçen gün arttığının göstergesidir. Yerleşmek için Döşemealtı'nın seçilme nedenleri, kent merkezinden uzak, doğayla iç içe ama kente ulaşım imkanlarının yakınlık nedeniyle uygun olmasıdır. Komşuluk ilişkileri ve apartman yaşamından farklı, müstakil evlerde eski mahalle yaşamının olması da tercih nedenidir. Yaşlı ve çocuklar için bahçeli evlerin tercih edilmesi söz konusudur. Kimi aileler daimî oturmakta, kimi aileler kentte bulunan evlerini de kullanmaktadır. Bir bahçe oluşturmak, ağaç dikmek, sebze yetiştirmek amaçlanmaktadır. Bahçe bakımı, ev temizliği, çocuk bakımı gibi işlerde köy sakinlerinden yardımcı eleman alınmaktadır. Köy sakinlerinin bir kısmı da tarlalarını sattıkları için berber, pideci, su ve tüp bayiliği, bakkallık, kasaplık, çeşitli benzin istasyonları ve büyük marketlerde işçilik, ev ve bahçe işlerinde yardımcılık yapmaktadır. Köylüler ve soylulaştırıcı kesim arasında yakın ilişkiler bulunmamaktadır. Kentten kıra gelen yerleşimcilerin kültürel ve sınıfsal özelliklerini kır ölçeğinde de sürdürmeye devam ettikleri ve köylülerle sınırlı etkileşim kurdukları gözlenmektedir. Döşemealtı mahalleleri sakinlerinin düzenli olarak işleyen belediye otobüsleri sayesinde kent merkezi ile yoğun etkileşimi söz konusudur. Bölgeye sonradan yerleșen orta ve üst sosyo-ekonomik grupların hemen her ailede bir veya birden fazla otomobil sahipliği nedeniyle otobüs kullanımları sınırlı olup, ulaşım ve diğer sosyal etkileșim türleri açısından kırsal yerli grupla organik etkileşimleri yok denecek kadar azdır. Etkileşim daha ziyade ev ve bahçe hizmetleri nedeniyle yardımcı almaları sürecinde ya da esnaflardan alışveriş sürecinde söz konusu olmaktadır. Döşemealtı bölgesine göç eden, yerleşen kesim içinde yurt dışına çalışmak için giden ve dönen aileler de yer almaktadır. Bu kesimde yer alan aileler yılın belli aylarında evlerinin kapısını açmakta ve daha sonra tekrar Batı Avrupa ülkelerine dönmektedir. Bazıları emeklilikten sonra tamamen Döşemealtı'nda yaşamlarını sürdürmektedir.

Yaşar Okudan doktora tez çalışmasında kentsel ve kırsal aktörlerin perspektifinden kentlerin çeperinde sürdürülebilir bir kent ve kır ilişkisi nasıl geliştirilebilir? Sorusunu sormakta ve Antalya Döşemealtı örneğinde konuyu incelemektedir. Tez çalışmasında seçilmiş örnekleme Döşemealtındaki sosyal ve mekânsal değişim ile ilgili hazırlanmış ölçek uygulanmış ve sonuçları değerlendirilmiştir.1980 Öncesi bir yerleşim sistemi Kent veya kır olarak ya da yerleşim büyüklüklerinin kademelenmesine göre tanımlanırdı. Kent tarım dışı faaliyetlerin yer aldığı 
mekansal formu ve sınırları belli yerleşimler olarak görülürken kır kentsel özelliklerin eksik olduğu belirli sınırlara sahip yerleşim alanları olarak tanımlanmıştır. 1980'lerden itibaren fordist üretimden post-fordist üretime geçiş ile birlikte değişen üretim biçimlerinin Küreselleşme ve neoliberal kentleşmenin etkileri ile birlikte dünyadaki tüm kentlerin sosyodemografik, ekonomik ve mekansal yapıları önemli ölçüde değişmektedir. Kır ile kenti ayırt etmek için kullanılan keskin göstergeler ve niceliksel eşikler anlamsız hale gelmeye başlamıştır. Bu çerçevede Antalya Döşemealtı örneğinde kırsal yapı üzerinde neoliberal kentleşmenin etkilerini ele almaktadır (Okudan, 2019).

Okudan'ın araştırmasında Döşemealtı'nın kentleşmesi konusunda bölge sakinlerinde, doğal ve tarımsal alanların ortadan kalkması nedeniyle olumsuz, ancak ticaretin artması, nüfus ve sosyalleşmenin farklı insanlarla tanışma fırsatı vermesi gibi nedenlerle de olumlu bakış açıları ortaya çıkmıştır. Döşemealtı bölgesinin göç alması, şehrin kalabalığı, gürültüsü ve yoğunluğundan kaçma ile de ilgilidir. Döşemealtı nüfusu daha azdır ve nüfus artış hızı düşüktür. Şehre yakındır ama aynı zamanda doğal yaşama sahiptir. Antalya dağlarla çevrili olduğu için şehrin büyümesi sınırlı kalmış ve kuzeye doğru büyümektedir. Döșemealtı'nın en önemli sorunları olarak ulaşım sorunları, sosyal sorunlar (eğitim ve kültürel ihtiyaçlar) ve mekânsal sorunlar (çarpık kentleşme) belirtilmiştir (Okudan,2019: 153-172).

Döşemealtı'nda toplam ekilebilir alan 2012 yılında 96835 dekardır. Aksu'dan sonra ikinci sıradadır, yani tarım arazisi açısından ikinci büyüklüktedir. 2016 yılında ise bu rakam 87124 dekar olmuştur. 6 yılda önemli bir azalma olmuştur.

“Calışma sahasında tarım topraklarının kaybedilmesinin nedenleri: Tarım topraklarının insanların şahsi menfaatleri nedeniyle imara açılması, plansız ve çarpık kentleșme, yanlış tarım politikaları ve yasal düzenlemeler, toprakların miras yasası nedeniyle küçülmesi, tarımın rantabl olmayışı ve bu nedenle tarım topraklarının farklı sektörlere kayması ve benzeridir. Tarım alanları, imalat sanayi ve turizm baskısı altındadır." (Doğan, 2018: 187 -201)

Döşemealtı Bölgesi'nin sınırları içerisinde Antalya'nın en önemli su kaynağı olan Kırkgöz Gölü ve kaynakları, önemli miktarda, orman varlığı, ciddi sayıda zeytin ağacı varlığı, Organize Sanayi Bölgesi, Toptancılar Sitesi, Kamyoncular Kooperatifi, Toplu Konut alanları, Karain Mağarası, Termessos antik kenti ve daha birçok üretim ve kültür ögesi bulunmaktadır. Anakente çok yakın olmasının yanında görece bozulmamış doğal çevresi ile Döşemealtı kentin dışındaki en cazip yerleşme alanı durumundadır. Döşemealtı'nın bu özelliğinin kendi felaketine neden olmasından korkulur. Bunun yaratacağı önemli risklerin başında birçok yerde olduğu gibi doğal ve tarihi çevrenin uğrayacağı tahribat bulunmaktadır. (Ercenk, 2010; 214).

\section{Sonuç ve Öneriler}

Çalışmada, Döşemealtı bölgesinin yörük kışlak yerinden köye, köyden de kente dönüşümü anahatlarıyla ele alınmıștır. Antalya'nın batısı ve doğusunun artık yeterince kalabalıklaştığı düşünülürse Döşemealtı ilçesinin şehrin kuzeyinde gerek doğası ve iklimi gerek șehre yakınlığı ve sosyo-kültürel imkanları ile önemli bir çekim merkezi olduğu belirtilebilir.

Antalya iline ve yöre halkının ekonomisine yön veren Organize Sanayi Bölgesinin sınırları içerisinde olduğu, Antalya Bilim Üniversitesi, Antalya Y. Ziya Öner Fen Lisesi ve Antalya Erünal Sosyal Bilimler Lisesi gibi önemli eğitim kurumlarına ev sahipliği yaptığı, Toplu Konut İdaresi konutlarının bulunduğu, ilçe olması nedeniyle çeşitli kamu kurumlarının yer aldığı, pek çok özel eğitim ve sağlık kuruluşlarının yer seçtiği, Termessos, Karain Mağarası, Dağbeli Ariassos, Bademağacı Höyüğü, Kırkgöz Han ve Evdir Han gibi önemli antik yerleşim ve konaklama yerlerini de bünyesinde barındırdığı görülen Döşemealtı İlçesinin; hızla artan inşaat alanları, lüks konut projeleri ve nüfusu ile Antalya ilinde bir cazibe merkezi olmaya devam ettiği gözlenmektedir. Ancak kentin baskısının doğal ve tarihi çevreye vereceği zararlar düşünülmesi gereken konular arasındadır. Yitirilen doğa ve kırsal yaşam bir daha geri getirilemeyecektir. 
Döşemealtı ilçesi, kırsal mekânın hızla metalaştığı, kırsal soylulaştırmanın sürdüğü, farklı toplumsal tabakaların yaşamını sürdürdüğü cazip bir yerleșim bölgesi haline gelmiş ve bu heterojen sosyal yapı, yeni sosyolojik araştırmalar için adeta bir laboratuvar işlevi görmeye başlamıştır.

Hakem Değerlendirmesi: Dışbağımsız.

Finansal Destek: Yazar bu çalışma için finansal destek almadığını beyan etmiştir.

Peer-review: Externally peer-reviewed.

Grant Support: The author received no financial support for the research, authorship, and/or publication of this article.

\section{Kaynakça/ References}

Mavisehirantalya. (2017). Antalya'nın Ilçeleri. 20 Mart 2021 tarihinde https://mavisehirantalya.wordpress.com/2017/05/04/antalyanin-ilceleri adresinden erişildi.

Çelik, M. E. (2018). Döşemealtı'na iskân edilen Karahacılı Aşireti ve yayla göç yolunun incelenmesi. B. Koçakoğlu, B. Karslı, D. Sustam, Z. Sula, H. İ. Yücel, ve A. Demir (Ed.), Antalya Kitabı- Selçukludan Cumhuriyete Sosyal Bilimlerde Antalya içinde (ss. 1057-1067). Konya: Palet Yayınlar.

Çiftçi-Yeşiltuna, D. (2016). Küreselleşme ve kırsal dönüşüm, komşu mahalleden butik siteye. Ankara: Nobel Yayıncilık.

Çilingir, T. ve Görgün E. K. (2018). Hızla üzerine kent gelen köyün, kentleșme ile imtihanı: Uzundere, Planlama 2018; (Ek 1). 139-151.

Doğan, M. (2018). Antalya şehrinin (Muratpaşa, Kepez, Döșemealtı, Aksu, Konyaaltı) gelişmesinde etkili olan faktörler. International Journal of Geography and Geography Education, (38), 187-201. doi: 10.32003/iggei.426712.

Döșemealtı Belediyesi (2016). Döşemealtı/Konum. 20 Mart 2021 tarihinde http://www.dosemealti.bel.tr/tr/m/dosemealti/konum.html adresinden erişildi.

Ercenk, G. (2010). Dünden bugüne Döșemealtı. Antalya: Atso Yayını.

Güçlü, M. (1997). XX. Yüzyılın ilk yarısında Antalya. Antalya: Atso Yayını.

Güçlü, M. (2006). Batı Toroslarda dağ geçitleri, A. Erdoğru, (Ed.) Tarihin içinden içinde (ss.312345). İstanbul: IQ Kültür Sanat Yayıncılık.

Güçlü, M. (2018). Antalya 1932. İzmir: Er Yayıncılık.

Hansu, L. (2015). Antalya Büyükşehir Belediyesi plan kararlarının 6360 Sayılı Büyükşehir Kanunu kapsamında değerlendirilmesi. Planlama, 25(2), 85-92.

Kapan, K. (2018). Turizm faaliyetlerinin şehirsel gelișmeye etkileri: Antalya örneği. (Yayınlanmamış Doktora Tezi), İstanbul Üniversitesi, Sosyal Bilimler Enstitüsü, Coğrafya Anabilim Dalı, İstanbul.

Keyder, Ç. ve Zafer Y. (2015). Bildiğimiz tarımın sonu, küresel iktidar ve köylülük. İstanbul: İletişim Yayınları.

Nurettin V. L. (1944). Antalya Íkinci Dünya Harbi içinde nasıl güzelleșebildi? İstanbul: Kenan Matbaasl. 
Nüfusu. (2017). Döşemealtı Nüfusu. 20 Mart 2021 tarihinde adresi: https://www.nufusu.com/ ilce/dosemealti_antalya-

nufusu\#: :text=D\%C3\%B6\%C5\%9Femealt\%C4\%B1\%20n\%C3\%BCfusu $\% 202020 \% 20 y \% C 4 \% B 1 l$ \%C4\%B1na\%20g\%C3\%B6re\%2069.300 adresinden erișildi.

Okudan, Y. (2019). How to develop a sustainable rural-urban fringe (ruf) from perspective of urban and rural actors? The case of Döșemealtı in Antalya. (Yayınlanmamış Yüksek Lisans Tezi), ODTÜ, Fen Bilimleri Enstitüsü, Şehir Planlama Anabilim Dalı, Ankara.

Orhan, G. ve Güneş-Yücel Y., (2019). Kırsal mekânın metalaşması ve soylulaştırmanın köy hâli: Doğanbey Köyü'nün dönüşümü. MAD Journal, 1(8). 8-42.

Özdemir, T. (1943-1944). Antalya'da eğitmenli okul faaliyeti. Türk Akdeniz, Antalya Halkevi Dergisi, (29-30-31), 7-10.

Özen, M. A. (2019). Küreselleşme sürecinde kırsalın dönüşümü ve tüketim: Bursa Cumalıkızı örneği. (Yayınlanmamış Yüksek Lisans Tezi). Bursa Uludağ Üniversitesi, Sosyal Bilimler Enstitüsü, Çalışma Ekonomisi ve Endüstri İlișkileri Anabilim Dalı, Bursa.

Özgen, N, (2018). Doğa ve toplum. N. Özgen (Ed.). Sosyal coğrafya içinde, Pegem Yayınları.

Perkins, H.C. (2006). Commodification: Resourcing rural areas. P. Cloke, T. Marsden ve P. Mooney (Ed.), Handbook of rural studies (ss.243-258). London: Sage Publications,

Saraçoğlu, H. (1989). Akdeniz Bölgesi, MEB Öğretmen Kitapları Dizisi, 175. İstanbul.

Sarı, C., Demirkaya, H., Kurt, S. ve Çeçen, B. (Eds.). (2012). Dünden Bugüne Antalya (2 ed.). Antalya: T. C. Antalya Valiliği İl Kültür ve Turizm Müdürlüğü Yayınları.

Şen, B. (2005). Soylulaştırma: Kentsel mekânda yeni bir ayrışma biçimi. H. Kurtuluş (Ed.), İstanbul'da kentsel ayrışma içinde. İstanbul: Bağlam Yayıncılık.

TUiK, (2020) Adrese dayalı nüfus tespit sistemi. 20 Mart 2021 tarihinde https://data.tuik.gov.tr/Bulten/Index?p=Adrese-Dayali-Nufus-Kayit-Sistemi-Sonuclari-202037210 adresinden erişildi.

Uysal, A. B. (2017). Kırsalda koruma ve soylulaştırma ikilemi. Ege Mimarlık Dergisi, 36-39.

Başaran Uysal, A. ve Sakarya, İ. (2013). Kırsal soylulaştırma ve turizmin kırsal yerleşimlere etkileri: Adatepe ve Yeşilyurt Köyleri. G. Güldal, ve M.G. Fehim (Ed.), 8 Kasım Dünya Şehircilik Günü 36. Kolokyumu, Bildiriler kitabı (7-8-9 Kasım 2012) (ss.579-598). TMMOB Şehir Plancıları Odası, Ankara.

Ülken, H. Z., Kösemihal N. Ş. ve Tanyol, C. (1950). Karataş Köyü monografisi. Sosyoloji Dergisi, 85103.

Williams, P. (2015). Mekansal yeniden inşa ile sınıf oluşumu Avustralya Britanya ve Birleşik Devletlerdeki mutenalaştırmaya ilişkin bir yeniden değerlendirme. Smith N. ve Williams P. (Ed.) Kentin mutenalaştırılması içinde (ss. 83-111). İstanbul: Yordam Kitap.

Yenigül, S. B. ve Cihangir-Çamur K. (2013). Saçaklanma Dinamiklerinin yerleşimlerin dönüşümüne etkisi: Kırsaldan kentsele Ankara/Pursaklar. İdealkent, 4 (9), 198-231.

Yenigül, S. B. (2017). Kırsal kalkınma politikalarında yeni yaklaşımlar ve bu yaklaşımların Türkiye'nin kırsal kalkınma politikalarına etkisi. Planlama 27 (1), 16-25. doi: 10.14744/planlama.2016.47450.

Yenigül, S. B. (2016). Kırsal soylulaştırma: Soylulaştırma sürecinin kırsaldaki yansımaları. Mimarlık Dergisi (391), 61-65. 